\title{
STUDI PERILAKU SEKS MENYIMPANG TERHADAP KEJADIAN HIV FASE LATEN PADA KOMUNITAS LELAKI SEKS LELAKI (LSL) DI LSM KOMPEDA SURABAYA
}

\author{
Erika Martining Wardani ${ }^{1}$, Arif Helmi Setiawan ${ }^{2}$, Difran Nobel Bistara ${ }^{3}$ \\ ${ }^{1}$ Prodi S1 Keperawatan, FKK, Universitas Nahdlatul Ulama Surabaya, Indonesia \\ ${ }^{2}$ Prodi Ners, FKK, Universitas Nahdlatul Ulama Surabaya, Indonesia \\ ${ }^{3}$ Prodi D3 Keperawatan, FKK, Universitas Nahdlatul Ulama Surabaya, Indonesia \\ email : erika@unusa.ac.id
}

\begin{abstract}
ABSTRAK
Perilaku seksual menyimpang untuk mendapatkan kenikmatan seksual salah satunya adalah LSL. Hubungan seks anal (melalui dubur) paling berisiko terjadinya infeksi HIV karena lapisan dubur sangat tipis, sangat mudah dirusak saat berhubungan seks. Seseorang yang terinfeksi oleh virus HIV pada saat diperiksa antibodinya akan terdeteksi pada fase laten sekitar 1-20 bulan. Tujuan penelitian ini untuk mengetahui gambaran perilaku seks menyimpang terhadap kejadian HIV fase laten pada komunitas LSL. Penelitian ini menggunakan metode deskriptif survey. Sampel dalam penelitian ini sebanyak 65 responden, dengan kriteria inklusi yaitu responden yang bergabung dalam LSM Kompeda Surabaya dan berada dalam fase laten (dibuktikan dengan titer antibodi positif HIV). Teknik pengambilan sampel menggunakan accidental sampling. Analisa data menggunakan univariat. Penelitian ini menunjukan bahwa terbanyak adalah usia remaja akhir berusia 17-25 tahun $(58,5 \%)$ dengan pendidikan SMA $(55,4 \%)$ dan mayoritas sudah disirkumsisi (97\%). Studi perilaku menyimpang pada kelompok ini diantaranya : melakukan hubungan seksual dengan lebih satu orang/thereesome $(52, \%)$, penggunaan kondom $(40 \%)$; seksual anal $(53,8 \%)$, mengeluarkan sperma didalam anus (52,3\%); seksual oral (47,7\%), mengeluarkan sperma di dalam mulut $(50,8 \%)$; bergantian memasukan jari ke anus responden $(52,3 \%)$ dan pasanganya $(50,8 \%)$; rimming pada dirinya sendiri tidak pernah $(53,8 \%)$ dan kadang-kadang ke pasanganya $(61,5 \%)$; interfemoral coitus, responden $(53,8 \%)$ dan pasanganya $(52,3 \%)$; tidak pernah bergantian menggunakan alat bantu seks $(87,7 \%)$. Perilaku seksual kelompok LSL di LSM Surabaya tergolong beresiko menularkan HIV/AIDS. Penting memberikan pelayanan kesehatan secara proaktif dalam peningkatkan pengetahuan tentang perilaku beresiko HIV/AIDS.
\end{abstract}

Kata Kunci : Studi perilaku, fase laten, LSL, HIV/AIDS.

\begin{abstract}
Sexual deviant behavior to get sexual pleasure one of them is MSM. Anal sex (through the anus) is most at risk of HIV infection because the anal layer is very thin, very easily damaged during sex. Someone who is infected by the HIV virus when tested for antibodies will be detected in the latent phase for about 1-20 months. The purpose of this study was to find a picture of sexual deviant behavior towards the latent phase of HIV in the MSM community. This research uses descriptive survey method. The sample in this study were 65 respondents, with inclusion criteria, namely respondents who joined the NGO Kompeda Surabaya and were in a latent phase (as evidenced by HIV positive antibody
\end{abstract}


titers). The sampling technique uses accidental sampling. Data analysis uses univariate. This study shows that the majority are late teens aged 17-25 years (58.5\%) with high school education (55.4\%) and the majority have been circumcised (97\%). Studies of deviant behavior in this group include: sexual intercourse with more than one person I thereesome (52,\%), condom use (40\%); anal sex (53.8\%), excrete sperm in the anus $(52.3 \%)$; oral sex $(47.7 \%)$, excrete sperm in the mouth (50.8\%); alternately inserting fingers into the anus of respondents (52.3\%) and their partners (50.8\%); rimming in itself never $(53.8 \%)$ and sometimes to the partner (61.5\%); interfemoral coitus, respondents (53.8\%) and partners (52.3\%); never alternately using sex aids (87.7\%). Sexual behavior of MSM in Surabaya is classified as at risk of transmitting HIV / AIDS. It is important to provide proactive health services in increasing knowledge about HIV / AIDS risk behavior.

Keywords : Behaviour Study, fase laten, LSL, HIV/AIDS 


\section{PENDAHULUAN}

LGBT merupakan perilaku yang menjadi salah satu fenomena yang terjadi di sepanjang sejarah manusia yang mana merupakan perilaku seksual meyimpang dilakukan oleh kelompok lesbian, gay, biseksual, dan transgender. Istilah ini digunakan untuk menggantikan istilah kaum gay karena tidak mewakili orang-orang dengan orientasi seksual lain. Lesbian, gay, biseksual, dan transgender adalah istilah terkait orientasi seksual (Papilaya, 2016). Perilaku seksual yang menyimpang muncul pada seseorang memiliki kecenderungan untuk mengarahkan rasa ketertarikan, romantisme, emosional, dan seksualnya kepada pria, wanita, atau kombinasi keduanya (Douglas, Markus, 2015).

Prevalensi LGBT di seluruh dunia sekitar $10 \%$, yaitu 750 juta dari 7,5 milyar penduduk yang ada di dunia. Amerika Serikat merupakan negara pertama dengan jumlah komunitas LGBT terbanyak didunia, dan juga negara pertama yang melegalkan pernikahan sejenis tahun 2015 (ConQ, 2015). Data dari Routers, Centers for Disease Control and Prevention (CDC) memperkirakan ada 1,1 juta masyarakat Amerika Serikat yang mengidap HIV (Human Immunodeficiency virus). CDC mengungkapkan hanya dengan $4 \%$ pria homoseksual yang berhubungan seks dengan sesama jenis, akan menyebabkan mereka mewakili $66 \%$ dari infeksi baru di negara tersebut. Indonesia merupakan negara berkembang urutan ke 5 di Asia yang memiliki resiko tinggi terhadap penyakit HIV/AIDS, penyakit ini dapat menyebabkan kematian (Kemenkes RI, 2014). Salah satu populasi yang beresiko tinggi terkena Infeksi Menular Seksual (IMS) dan HIV/AIDS adalah Lelaki Suka dengan Lelaki (LSL) dikarenakan sering bergantiganti pasangan (Carmelita et al., 2017).

Jumlah HIV/AIDS di Jawa Timur sebanyak 18.243. Faktor risiko penularan terbanyak melalui hubungan seksual berisiko heteroseksual $(69,6 \%)$, penggunaan alat suntik tidak steril $(9,1 \%)$, diikuti homoseksual $(5,7 \%)$ dan penularan melalui perinatal (2,9\%) (Depkes, 2017). Hasil pemetaan komisi penanggulangan AIDS Kota Surabaya tahun 2011 terhadap 5 (lima) populasi berisiko menunjukkan bahwa WPS 2.975 orang, pelanggan WPS 14.577 orang, Waria 640 orang, LSL 1.325 orang dan Penasun 767 orang.

Perilaku seksual LSL merupakan faktor beresiko terinfeksi HIV-AIDS namun memerlukan waktu untuk mendeteksinya karena antibodi dapat dideteksi pada fase laten sekitar 1-20 bulan dimana virus seakan berhenti berkembang namun apabila diperiksa titer antibodinya terhadap HIV tetap positif sehingga penderita bisa menularkan HIV pada orang lain lewat cara-cara seksual, tranfusi dan pemakaian alat suntik yang terinfeksi (Smeltzer \& Bare, 2013).

Upaya preventif merupakan tindakan prioritas dalam penanggulangan HIV/AIDS. Hal ini berkaitan erat dengan situasi penularan HIV/AIDS yang ada di masyarakat. Pencegahan HIV/AIDS dapat dilakukan dengan meningkatkan pengetahuan dan sikap masyarakat tentang HIV/AIDS melalui berbagai upaya promosi kesehatan dengan pemberian informasi, edukasi, dan komunikasi (KIE) sesuai dengan budaya dan agama setempat seperti penyuluhan dan kampanye, media elektronik, media cetak dan sebagainya (Kemenkes, 2011).

\section{METODE PENELITIAN}

Metode penelitian ini menggunakan jenis deskriptif survey. Populasi dalam penelitian ini adalah semua laki-laki yang termasuk dalam kelompok LSL yang beresiko terinfeksi HIV yang datang ke LSM KOMPEDA Surabaya sebanyak 78 orang. Jumlah sampel yang digunakan adalah 65 orang, yang memenuhi kriteria 
inklusi yaitu kelompok LSL yang bergabung dalam LSM KOMPEDA Surabaya, berada dalam fase laten (dibuktikan dengan titer antibodi positif HIV) serta bersedia menjadi responden. Penelitian ini menggunakan accidental sampling. Variabel pada penelitian ini adalah variabel tunggal yaitu studi perilaku seks menyimpang. Instrumen yang digunakan adalah kuesioner. Lokasi penelitian ini dilakukan di LSM KOMPEDA Surabaya.

\section{HASIL DAN PEMBAHASAN}

\section{Data Umum}

Tabel 1. Distribusi frekuensi data demografi komunitas LSL $(n=65)$

\begin{tabular}{|c|c|c|c|c|}
\hline \multirow{2}{*}{$\frac{\text { No }}{1}$} & \multicolumn{2}{|c|}{ Karakteristik Responden } & \multirow[t]{2}{*}{ Frekuensi (n) } & \multirow[t]{2}{*}{ Presentase $(\%)$} \\
\hline & Usia & & & \\
\hline & Remaja Akhir & $(17-25)$ & 38 & 58,5 \\
\hline & Dewasa Awal & $(26-35)$ & 20 & 30,8 \\
\hline & Dewasa Akhir & $(36-45)$ & 6 & 9,2 \\
\hline & Lansia Awal & $(46-55)$ & 1 & 1,5 \\
\hline & Lansia Akhir & $(56-65)$ & 0 & 0 \\
\hline & Jumlah & & 65 & 100 \\
\hline 2 & Pendidikan Terakhir & & & \\
\hline & SD & & 2 & 3,1 \\
\hline & SMP & & 2 & 3,1 \\
\hline & SMA & & 36 & 55,4 \\
\hline & Diploma & & 6 & 9,2 \\
\hline & Sarjana & & 18 & 27,7 \\
\hline & Magister & & 1 & 1,5 \\
\hline & Jumlah & & 65 & 100 \\
\hline 3 & Sirkumsisi & & & \\
\hline & Sudah & & 63 & 97 \\
\hline & Belum & & 2 & 3 \\
\hline & Jumlah & & 65 & 100 \\
\hline
\end{tabular}

Berdasarkan tabel 1 diatas diperoleh data bahwa usia responden yang termasuk dalam kelompok Lelaki Suka Lelaki (LSL) setengahnya berusia remaja akhir sebanyak 38 orang $(58,5 \%)$ dengan usia 17-25 tahun. Tabel tersebut juga menunjukan 36 orang $(55,4 \%)$ memiliki pendidikan terakhir SMA. Responden yang sudah sirkumsisi sebanyak 63 orang $(97 \%)$.

Hal ini dikaitkan dengan aktivitas yang tinggi pada usia ini membuat banyak usia produktif melakukan perilaku seksual beresiko (Sufa, 2013). Menurut hasil penelitian Winarsih (2014) pada usia remaja akhir banyak pengalaman yang muncul mengenai perilaku seksual, hal itu dikarenakan rasa ingin tahu dan pengaruh lingkungan. Homoseksualitas banyak ditemukan di kalangan muda dan pelajar atau mahasiswa karena pada usia muda tersebut mereka lebih sering bertemu di klub malam, karaoke, sauna, tempat seks komersial, kencan melalui internet maupun telepon genggam, dan tempat-tempat seperti kolam renang, tempat olahraga dan fitness, maupun toilet (Asia Pacific Coalition on Male Sexual Health, 2010). Usia remaja memiliki kecenderungan rasa ingin tahu yang lebih sehingga ingin mencoba hal baru, pengaruh lingkungan yang kurang baik dan pengalaman masa lalu (terkait perilaku seks menyimpang) yang dialami dan menyebabkan trauma merupakan faktor yang bisa menyebabkan seorang remaja 
terjerumus pada kenakalan remaja yang salah satunya terkait perilaku seksual yang menyimpang.

Tingkat pendidikan dari hasil penelitian didapatkan sebagian besar responden berpendidikan Sekolah Menengah Keatas (SMA). Hal ini sesuai dengan laporan dari STBP pada kelompok beresiko tahun 2013 yang menyatakan sebagian besar berpendidikan terakhir SMA/ sederajat. Menurut Notoadmojo (2017) dengan pendidikan yang cukup baik terjadi proses pertumbuhan, perkembangan dan perubahan kearah yang lebih dewasa, lebih baik dan matang pada individu, kelompok ataupun masyarakat. Individu dengan pendidikan SMA seharusnya sudah dapat memahami informasi tentang HIV/AIDS.

Sunat atau sirkumsisi sering dilakukan oleh masyarakat bukan hanya sekedar alasan agama, tetapi juga karena alasan kesehatan. Mengingat sirkumsisi berkaitan dengan penularan HIV/AIDS sesuai dengan WHO (2013) yang menjelaskan sunat laki-laki mengurangi resiko penularan HIV sekitar $60 \%$. Sunat dapat mengurangi risiko terinfeksi HIV pada pria yang kerap terpapar HIV.

\section{Data Khusus}

a. Perilaku seksual beresiko

Tabel 2. Perilaku seks menyimpang pada komunitas LSL ( $\mathrm{n}=65)$

\begin{tabular}{|c|c|c|}
\hline $\begin{array}{l}\text { Perilaku seks } \\
\end{array}$ & Frekuensi (n) & Presentase $(\%)$ \\
\hline \multicolumn{3}{|c|}{$\begin{array}{l}\text { Seks dengan lebih dari satu orang atau } \\
\text { threesome }\end{array}$} \\
\hline Kadang-kadang & 34 & 52,3 \\
\hline Tidak pernah & 31 & 47,7 \\
\hline \multicolumn{3}{|l|}{ Penggunaan kondom } \\
\hline Kadang-kadang & 7 & 9,2 \\
\hline Tidak pernah & 33 & 50,8 \\
\hline Selalu & 26 & 40 \\
\hline \multicolumn{3}{|l|}{ Seksual anal } \\
\hline Selalu & 19 & 29,3 \\
\hline Kadang - kadang & 35 & 53,8 \\
\hline Tidak pernah & 11 & 16,9 \\
\hline \multicolumn{3}{|c|}{ Mengeluarkan sperma di dalam anus } \\
\hline Selalu & 5 & 7,7 \\
\hline Kadang - kadang & 34 & 52,3 \\
\hline Tidak pernah & 26 & 40 \\
\hline \multicolumn{3}{|l|}{ Seksual oral } \\
\hline Selalu & 22 & 33,8 \\
\hline Kadang - kadang & 31 & 47,7 \\
\hline Tidak pernah & 12 & 18,5 \\
\hline \multicolumn{3}{|c|}{ Mengeluarkan sperma di dalam mulut } \\
\hline Selalu & 1 & 1,5 \\
\hline Kadang - kadang & 33 & 50,8 \\
\hline Tidak pernah & 31 & 47,7 \\
\hline \multicolumn{3}{|c|}{ Bergantian memasukan jari ke anus responden } \\
\hline Selalu & 1 & 1,5 \\
\hline Kadang - kadang & 34 & 52,3 \\
\hline Tidak pernah & 30 & 46,2 \\
\hline
\end{tabular}


Bergantian memasukan jari ke anus pasangan

\begin{tabular}{lcc}
\hline Selalu & 1 & 1,5 \\
Kadang - kadang & 33 & 50,8 \\
Tidak pernah & 31 & 47,7 \\
\hline Rimming (reponden) & 2 & \\
\hline Selalu & 28 & 3,1 \\
Kadang - kadang & 35 & 43,1 \\
Tidak pernah & 53,8 \\
\hline Rimming (pasanganya) & 3 & \\
\hline Selalu & 40 & 4,7 \\
Kadang - kadang & 22 & 61,5 \\
Tidak pernah & & 33,8 \\
\hline Interfemoral coitus (reponden) & 2 & 3,1 \\
\hline Selalu & 35 & 53,8 \\
Kadang - kadang & 28 & 43,1 \\
Tidak pernah & & 6,2 \\
\hline Interfemoral coitus (pasanganya) & 4 & 52,3 \\
\hline Selalu & 34 & 41,5 \\
Kadang - kadang & 27 & 3,1 \\
Tidak pernah & & 9,2 \\
\hline Saling bergantian alat bantu seks (reponden) & 2 & 3,1 \\
\hline Selalu & 6 & 9,2 \\
Kadang - kadang & 57 & 87,7 \\
Tidak pernah & & \\
\hline Saling bergantian alat bantu seks (pasanganya) & 2 & \\
\hline Selalu & 6 & \\
Kadang - kadang & 57 & \\
Tidak pernah & & \\
\hline
\end{tabular}

Tabel 2 didapatkan data sebagian besar responden dalam melakukan hubungan seksual dengan lebih satu orang atau threesome (523\%) dan menggunakan kondom (50,8\%). Hal ini menunjukkan bahwa sebagian orang pernah berperilaku beresiko. Menurut Laksana \& Lestari (2013) dalam penelitiannya menjelaskan bahwa sebagian besar seorang homoseksualitas ratarata memilih 6-7 pasangan, mereka memiliki lebih dari satu pasangan hubungan seks dan bergonta-ganti pasangan seks. Hal ini sejalan pada penelitian Firdaus (2013) bahwa homoseksualitas cenderung memilki banyak pasangan seks. Penelitian Sudin (2015) didapatkan hasil perilaku seksual dengan bergonta-ganti pasangan sehingga banyak yang ditemukan terinfeksi HIV dilakukan oleh sebagian besar kelompok homoseksualitas. Menurut (Kemenkes RI, 2011). HIV tersebut akan terbawa dalam cairan sperma sehingga jika salah satu pasangan terinfeksi HIV dan ditemukan luka pada organ seks maka dengan mudah dapat menularkan virus ke pasanganya.

Hasil penelitian menunjukkan bahwa kelompok LSL hampir setengahnya tidak menggunakan kondom saat melakukan hubungan seksual yaitu 50,8\%. Menurut Komisi Penanggulangan AIDS (2010) dari 266 homoseksualitas yang menggunakan kondom secara sebanyak 97 orang atau sebesar 36\%. Hal ini sejalan pada penelitian Laksana \& Lestari (2013) pada kelompok homoseksualitas penggunaan kondom masih cenderung rendah, yaitu sebesar $50 \%$. 
Penurunan HIV melalui pertukaran cairan tubuh yang dapat terjadi ketika melakukan hubungan seksual dapat dicegah dengan menggunakan alat kontrasepsi seperti kondom. Kondom adalah sarana terbukti mencegah infeksi HIV. terlepas dari itu, tidak ada pelindung yang 100\% efektif (WHO, 2013).

Penelitian ini mengungkap bahwa banyak responden melakukan anal seks $(53,8)$, baik melakukan anal sebagai pelaku atau penerima dan melakukan anal dengan mengeluarkan sperma di dalam anus. Menjadi pelaku atau penerima selama berhubungan anal seks berkaitan dengan resiko tinggi infeksi HIV/AIDS (AidsMeds, 2012). Berdasarkan hasil penelitian Laksana \& Lestari (2010) sebanyak $72 \%$ homoseksualitas melakukan anal seks. Menurut Wahyuningsih (2012) perilaku berhubungan secara anal sangat beresiko terinfeksi HIV. Anus tidak seperti organ reproduksi wanita (vagina) yang dapat melubrikasi (melumasi) saat merasa terangsang. Melakukan hubungan seks melalui anal beresiko terjadinya luka atau lecet pada jaringan anus karena struktur anus yang lebih ketat dibanding vagina sehingga akan mudah bagi virus HIV untuk masuk kedalam darah.

Berdasarkan tabel 2 diperoleh data sebagian besar responden melakuan hubungan seks oral $(47,7 \%)$ baik sebagai pelaku atau penerima, namun kebanyakan ahli sepakat bahwa seks oral bukan merupakan perilaku yang beresiko tinggi menularkan HIV, pernyataan tersebut berdasarkan hasil penelitian Dwilaksono \& Rahardjo (2014) mengungkapkan bahwa fellatio (oral seks) memiliki tingkat resiko rendah terhadap penularan HIV/AIDS di banding dengan anal seks. Pernyataan tersebut diperkuat dari penjelasan AidsMeds (2012) yang menyatakan bahwa oral seks dapat berpotensi penularan virus HIV jika terdapat luka terbuka di mulut yang menjadi perantara penulaan virus HIV. Air mani yang keluar (ejakulasi) pada ODHA melalui mulut penerima dimana terjadi kerusakan pada jaringan dalam mulut seperti sariawan, gusi berdarah dan infeksi mulut lainnya akan meningkatkan resiko penularan HIV dari seks oral.

Penelitian ini juga diperoleh data tentang pelaku seksual aktif pada perilaku seksual melakukan seksual dengan memasukan jari ke anus pasangan sebagian besar melakukannya baik pelaku $(50,8 \%)$ ataupun penerima $(52,3 \%)$. Hal ini sejalan dengan hasil penelitian Sudin (2015) homoseksual melakukan hubungan seks dengan memasukkan jari ke anus pasanganya agar anus dibuat rileks dulu sebelum melakukan anal, karena jika langsung dimasukkan akan terasa kesakitan. Dimulai menggunakan satu jari lalu dengan menggunakan dua jari. Menurut AidsMed (2012) menjelaskan faktanya sampai sekarang belum pernah ada kasus penularan HIV melalui fingering (memasukkan jari ke dalam anus/ merangsang dengan jari). Perilaku ini beresiko menularkan HIV apabila orang tersebut tidak menjaga kebersihan tangannya baik akibat tanganya ada luka atau kukunya panjang yang mengakibatkan anusnya lecet.

Berdasarkan tabel 2 diperoleh hasil responden tidak pernah melakukan perilaku rimming (oral-anal) yaitu sebesar $(53,8 \%)$, sedangkan sebagian besar pernah melakukan ke pasangannya (61,5\%). Perilaku rimming dilakukan untuk memperoleh variasi dan kenikmatan, tetapi belum ada data yang menyatakan bahwa penularan HIV/AIDS melalui perilaku rimming (Kartono, 2009). Hal itu diperkuat dengan penelitian Sudin (2015) bahwa hubungan seks rimming hanya sebagai variasi seks. Anilingus/ rimming juga dianggap sebagai risiko yang tidak dapat diabaikan terutama untuk pasangan yang menerima. 
Hasil penelitian diperoleh hasil responden hampir setengahnya kadangkadang pernah melakukan interfemoral coitus (perilaku seksualitas dengan cara menggesek-gesekkan penis diantara dua paha) baik pelaku atau penerima. Interfemoral coitus sendiri yaitu perilaku memanipulasi penis dan zakar diantara dua paha atau alat kelamin kemaluan pasanganya. Perilaku seksual tersebut bisa menyebabkan perlukaan pada organ vital atau bagian yang mengunakan percing atau tindik yang menjadi jalan masuk HIV/AIDS (Kartono, 2009). Berdasarkan hasil penelitian Sudin (2015) bahwa interfemoral coitus akan beresiko apabila ada luka akibat gesekan. Interfemoral coitus dianggap sebagai faktor risiko yang dapat mengakibatkan seseorang terifeksi HIV karena luka terbuka merupakan port the entry HIV.

Penggunaan alat bantu seks, diperoleh data bahwa hampir seluruh responden tidak pernah melakukan saling bertukar alat bantu seks (boneka silikon maupun vibrator) ketika berhubungan seks. Bertukar alat bantu seks ketika berhubungan seks akan beresiko menularkan HIV, karena pada perilaku tersebut akan mengakibatkan dinding anus menjadi perforasi, hal itu dapat menjadi jalan masuk virus. Sifat virus HIV ini tidak bertahan lama hidup di luar tubuh inangnya (manusia), tetapi penularan melalui vibrator atau alat bantu lainya tetap beresiko (Kartono, 2009). Berdasarkan hasil penelitian Sudin (2015) bahwa homoseksualitas jarang memakai alat bantu ketika berhubungan seks, dikarenakan ada pasanganya yang sudah memiliki alat kelamin untuk memuaskan dirinya. HIV yang tidak berada di dalam tempat yang sesuai dengan hidupnya seperti dalam darah tidak dapat bertahan lama, sehingga pada keadaan tersebut sangat jarang sekali terjadi penularan bahkan hampir tidak ada kasus yang menularnya HIV melalui alat bantu seks.

\section{SIMPULAN DAN SARAN}

Penelitian yang telah dilakukan peneliti dapat disimpulkan disimpulkan bahwa perilaku seksual menyimpang pada kelompok LSL di LSM KOMPEDA Surabaya tergolong beresiko menularkan HIV/AIDS.

Saran kepada pihak LSM KOMPEDA untuk memberikan pelayanan kesehatan secara proaktif dapat memfasilitasi kelompok berisiko seks menyimpang seperti LSL dalam peningkatkan pengetahuan tentang HIV/AIDS melalui penyuluhan kesehatan. Diharapkan melalui penyuluhan kesehatan tersebut terjadi perubahan perilaku seks berisiko yang mengarah pada kejadian HIV/AIDS diantara kelompok LSL.

\section{DAFTAR PUSTAKA}

AidsMeds. (2012). How is HIV Transmitted?http://www.aidsmeds.com. Diakses tanggal 17 Maret 2019, jam 16.00 WIB.

APCOM. (2010). Addresing the Needs of Young Men Who Have Sex with Men. APCOM Policy Brief. 4:1-4.

ConQ.me. (2015). Lgbt Survey Edisi 1 Demografi Psikografi: ConQ; 2015.

Crews, Douglas., \& Crawford, Marcus. (2015). Exploring the Role of Being Out on a Queer Person's Self-Compassion. Journal of Gay \& Lesbian Social Services Vol. 27 (No. 2), pp. 172-186. 
Departemen Kesehatan. 2017. Profil Kesehatan Indonesia. Jakarta:Departemen Kesehatan RI.

Dwilaksono,W. Rahardjo, W. (2014). Kontrol Diri dan Perilaku Seksual Primisif pada Gay. Diakses pada 16 Juli 2019, jam 11.00 WIB.

Kartono, Kartini. (2009). Psikologi Abnormal dan Abnormalitas Seksual. Bandung: CV Mandar Maju .

Kemenkes RI. (2011). Modul Penggunaan Obat Rasional, Bina Pelayanan Kefarmasian : Jakarta.

Komisi Penanggulangan AIDS (KPA). (2012). Info HIV/AIDS.http://aidsyogya.or.id/2015/data-hiv-aids/1002. Diakses tanggal 10 April 2019, jam 19.00 WIB.

Laksana \& Lestari. (2013). Kontrol Diri dan Perilaku Seksual Permisif pada Gay. http://wahyu_r.staff.gunadarma.ac.id. Diakses 26 April 2019, jam 16.00 WIB.

Kunoli, Firdaus. (2013). Pengantar Epidemiologi Penyakit Menular : Untuk Mahasiswa Kesehatan Masyarakat, Jakarta: TIM.

Laksana \& Lestari. (2013). Kontrol Diri dan Perilaku Seksual Permisif pada Gay. http://wahyu_r.staff.gunadarma.ac.id. Diakses 26 April 2019, jam 16.00 WIB.

Notoatmodjo. (2017). Promosi Kesehatan dan Ilmu Perilaku. Jakarta: Rineka Cipta.

Papilaya, Jeanete Ophilia. (2016). Lesbian, Gay, Biseksual, Transgender (LGBT) \& Keadilan Sosial. Jurnal Linimasa.

NSmeltzer, Suzanne C \& Bare, Brenda G. (8/e). (2013). Brunner \& Suddarth's Textbook of Medical-Surgical Nursing. Philadelphia: Lippincott-Raven Publishers.

Sudin. (2015). Perilaku Seksual Berisiko Antara Laki-Laki Berhubungan Se ks dengan Sejenis (LSL)Terkait Penyebaran HIV Dan AIDS di Kota Makassar. Diakses pada 16 juni 2016, dari http://repository.unhas.ac.id:4001/digilib/files/disk1/411/--sudin-20522-115-sudin-).pdf

Sufa, I. G. (2013). 70 Persen Kasus HIV Baru Diderita Usia Produktif. http:www.tempo.co/ read/news/2013/10/28/078525282/70-Persen-KasusHIV-Baru -Dideritas-Usia-Produktif. Diakses tanggal 9 Juni 2019, jam 15.00 WIB.

Wahyuningsih, M. (2012). 4 Bahaya Melakukan Seks Lewat Anus. http://health.detik.com. Diakses pada 9 Juni 2019, jam 10.00 WIB.

WHO. (2013). HIV/AIDS. http;//www.who.int/features/qa/71/en. Diakses pada 9 juni 2019, jam 11.00 WIB.

Winarsih. (2014). Perilaku Seksual Komunitas Gay Kaitanya dengan HIV/AIDS. http://jurnal.fkip.uns.ac.id. Diakses 20 Mei 2019, jam 15.00 WIB. 